\title{
Exchange-Coupling in Magnetic Nanoparticles to Enhance Magnetostrictive Properties
}

H.B. Radousky, M. McElfresh, A. Berkowitz, G.P. Carman

January 31, 2002

U.S. Department of Energy

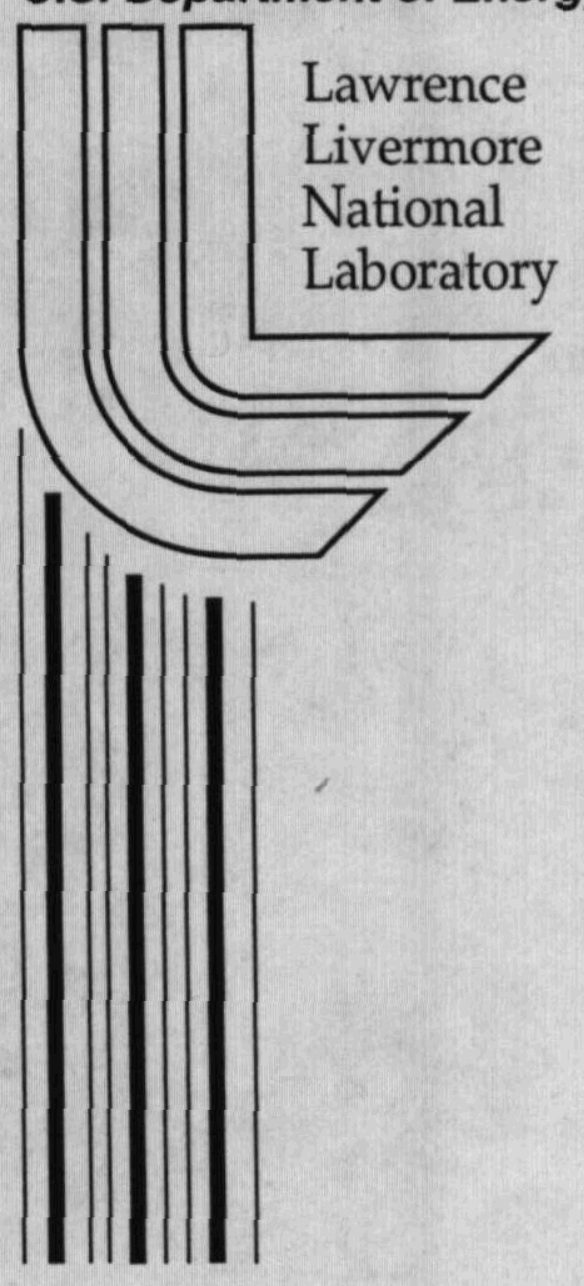




\section{DISCLAIMER}

This document was prepared as an account of work sponsored by an agency of the United States Government. Neither the United States Government nor the University of California nor any of their employees, makes any warranty, express or implied, or assumes any legal liability or responsibility for the accuracy, completeness, or usefulness of any information, apparatus, product, or process disclosed, or represents that its use would not infringe privately owned rights. Reference herein to any specific commercial product, process, or service by trade name, trademark, manufacturer, or otherwise, does not necessarily constitute or imply its endorsement, recommendation, or favoring by the United States Government or the University of California. The views and opinions of authors expressed herein do not necessarily state or reflect those of the United States Government or the University of California, and shall not be used for advertising or product endorsement purposes.

This work was performed under the auspices of the U.S. Department of Energy by the University of California, Lawrence Livermore National Laboratory under Contract No. W-7405-Eng-48.

This report has been reproduced directly from the best available copy.

Available electronically at http://www.doe.gov/bridge

Available for a processing fee to U.S. Department of Energy and its contractors in paper from

U.S. Department of Energy

Office of Scientific and Technical Information

P.O. Box 62

Oak Ridge, TN 37831-0062

Telephone: (865) 576-8401

Facsimile: (865) $576-5728$

E-mail: reports@adonis.osti.gov

Available for the sale to the public from

U.S. Department of Commerce

National Technical Information Service

5285 Port Royal Road

Springfield, VA 22161

Telephone: (800) 553-6847

Facsimile: (703) 605-6900

E-mail: orders@ntis.fedworld.gov

Online ordering: http://www.ntis.gov/ordering.htm

OR

Lawrence Livermore National Laboratory

Technical Information Department's Digital Library

http://www.llnl.gov/tid/Library.html 


\title{
FY 01 Feasibility Study 01-FS-005 \\ ERI Final Report
}

\section{Exchange-Coupling in Magnetic Nanoparticles to Enhance Magnetostrictive Properties}

\author{
H.B. Radousky, M. McElfresh \\ Lawrence Livermore National Laboratory, Livermore, California 94551
}

Ami Berkowitz

University of California, San Diego, San Diego, California

Gregory P. Carman

Mechanical \& Aerospace Engineering Department, University of California, Los Angeles, Los Angeles, California 90095

\section{Introduction}

Spark erosion is a versatile and economical method for producing particles of virtually any type of material that has a nominal conductivity: particles can be prepared in sizes ranging from a few $\mathrm{nm}$ to tens of $\mu \mathrm{m}$. The purpose of this feasibility study was to demonstrate the capability of making spherical particles of specific magnetic materials. We chose ( $\mathrm{Tb} \mathrm{Dy}) \mathrm{Fe}_{2}$ (Terfenol-D) due to its potential use as the magnetostrictive component in magneto-elastomer composites. We also chose to work with pure $\mathrm{Ni}$ as a model system. Improvements in the properties of magneto-elastomer composites have broad applications in the areas of sensor development, enhanced actuators and damping systems.

Spherical particles were prepared using spark erosion for both the Terfenol D and $\mathrm{Ni}$ systems. These materials were characterized using $\mathrm{x}$-ray diffraction, magnetization, and Scanning Electron Microscopy (SEM). Shown below in Fig. 1 is an SEM of the Terfenol-D particles and in Fig. 2 is an SEM for the Ni particles. In both cases, a distribution of spherical particles was produced, including nano-sized (sub-micron) particles.

The work on making the $\mathrm{Ni}$ particles into magnet-elastomer composites is described in the attached abstract. The work on producing the spherical particles by spark erosion is being prepared for submission to Journal of Materials Research. 


\section{Acknowledgement}

The research at University of California, Los Angeles, was supported through the Lawrence Livermore National Laboratory under Subcontract No. B522319. The research at University of California, San Diego, was supported through the Lawrence Livermore National Laboratory under Subcontract No. B522317. This work was performed under the auspices of the U. S. Department of Energy by the University of California, Lawrence Livermore National Laboratory under Contract No. W-7405-Eng-48 through the Materials Research Institute.

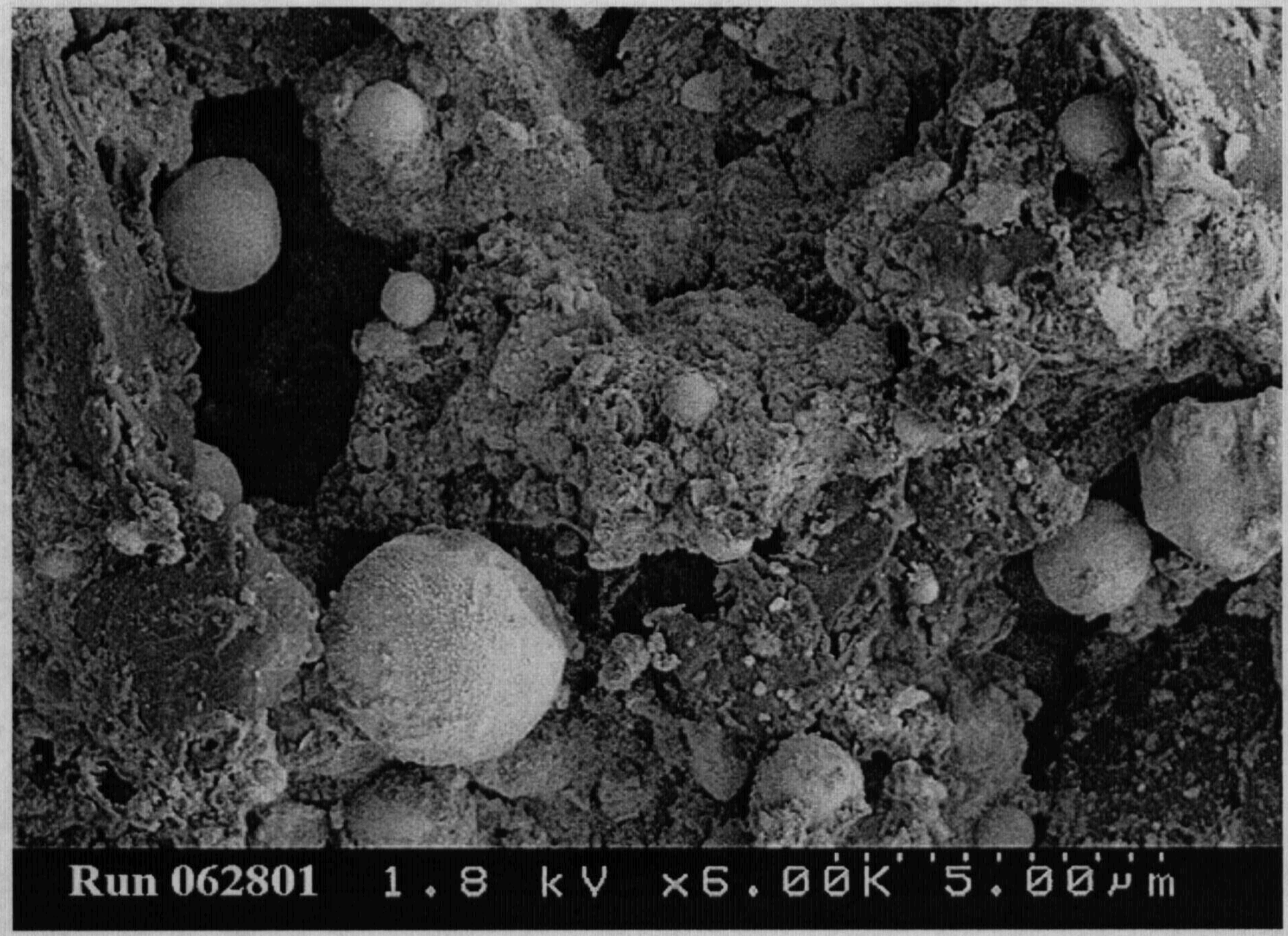

Figure 1. Terfenol-D particles produced by spark erosion. 


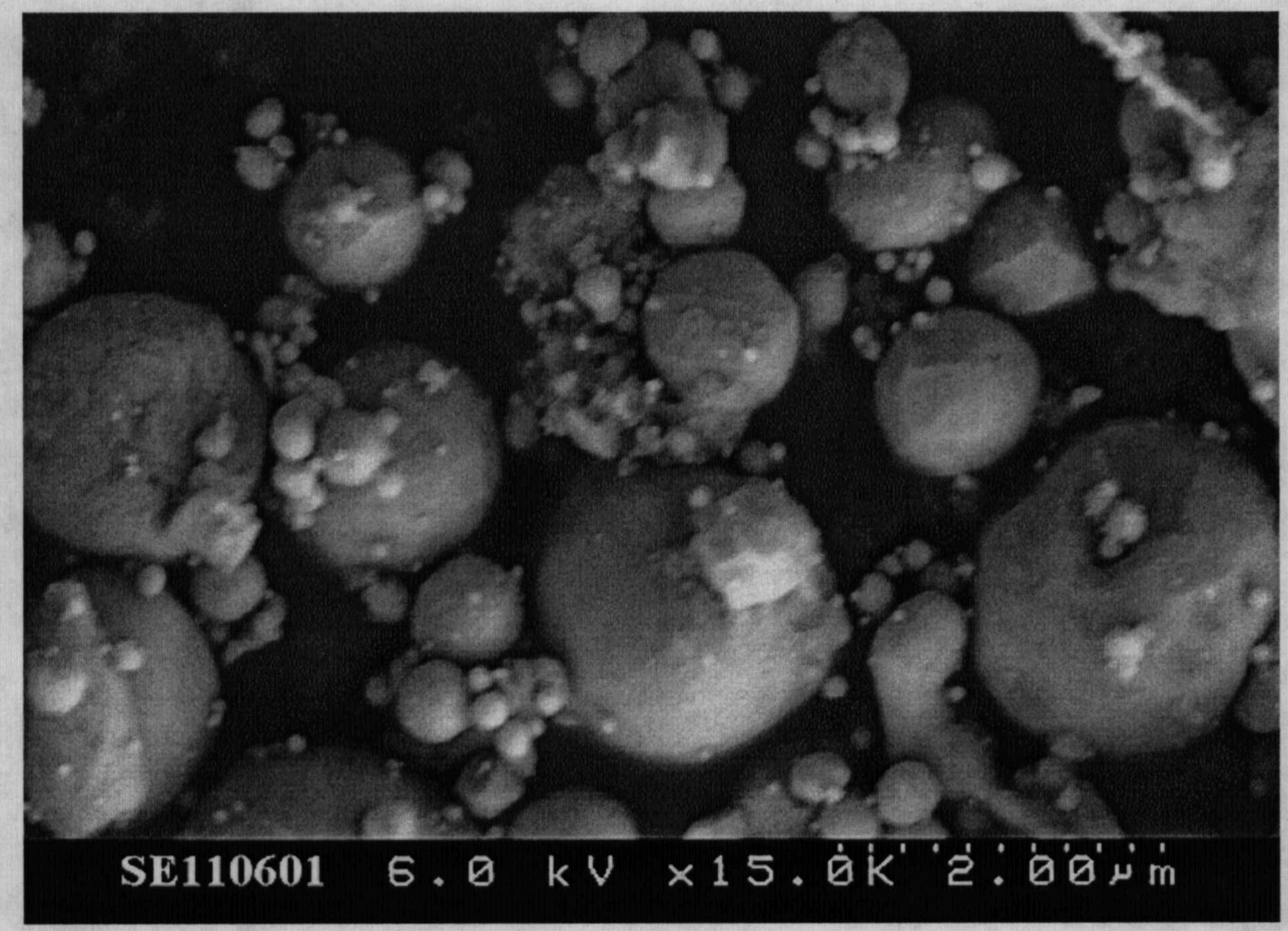

Figure 2. Nickel particles produced by spark erosion. 